being $\mathrm{R}$ for rehydration, $\mathrm{O}$ for oral fluid replacement, $\mathrm{S}$ for simultaneous intravenous rehydration, and $\mathrm{E}$ for education of mothers about diarrhoea and dehydration. This is very important and in large Indonesian cities a child's admission to hospital is often one of the few opportunities for this educational process to occur. This ROSE method is now being used on a nation-wide basis.

These results represent a marked improvement over recent years. In 1963 the mortality rate from childhood cholera in Jakarta was $46^{\circ}$." when glucose-saline was given intravenously. In 1973 the mortality rate dropped to $10^{\prime \prime}$ " when sodium bicarbonate was added to the intravenous fluid, in 1974 it dropped even further to $3 \cdot 5^{\circ} \mathrm{o}$ when Ringer's lactate was given intravenously followed by glucoseelectrolyte solution orally. This simple ROSE system could be used in large hospitals where facilities for intravenous therapy are available. Minor modifications, such as the substitution of sucrose for glucose, in the oral fluid should not adversely affect the results. Sucrose is much more readily available and much cheaper and has been shown to be very useful in the oral treatment of this disease. ${ }^{3}$

Michael Gracey

Princess Margaret Children's
Medical Research Foundation

Perth, Western Australia

SUHARJONO

$\mathrm{S}$ W ADNAN

SuTEjo

Department of Child Health,

University of Indonesia,

Jakarta, Indonesia

Hirschhorn, N, et al, New England fournal of Medicine,

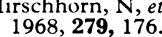

2 Pierce, N F, et al, Annals of Internal Medicine, 1969, 70, 1173 .

${ }^{3}$ Nalin, D R, Lancet, 1975, 1, 1400.

- Moenginah, P A, et al, Lancet, 1975, 2, 323.

\section{A case of reticulosis}

SIR,-Dr Stuart Carne and Dr J M Whitehouse's article (19 February, p 492) seems to me to confuse doctors' anxiety and patients' anxiety. All doctors believe that the greatest sin they can commit is to miss an early case of malignant disease in spite of the fact that there is very little hard evidence that finding malignant disease early improves the prognosis. So when the nurse-mother mentions the possibility of Hodgkin's disease up goes the doctor's level of anxiety and off he goes on the medical pursuit trail-eventually passing his anxiety on to the consultant, who promptly amplifies it.

I was positively sweating by the time I got to the end of the article, but none of the doctors gave me the feeling that they really believed that this child had Hodgkin's disease -they were too busy rationalising their own anxiety into "treating the mother's anxiety." But from the beginning I was expecting to be informed as to why the mother was anxious. $\mathrm{Had}$ she just had nursing experience of Hodgkin's disease or had she had some much closer experience in her own family or in a close family friend? If you are going to treat the mother's anxiety, then surely the first thing to do is to try to trace it back to its roots. If she had had a personal experience of this disease, then compare the onset in the case she had in mind with that of her healthy son. That might relieve her anxiety forthwith. Alternatively, if it was just nursing experience, she might have accepted the general practitioner's diagnosis-especially if this were reinforced with a simple blood test and two weeks on cephalexin. I am not surprised that this child developed postoperative complications.

F E S HatField

Ongar, Essex

\section{Rising incidence of childhood diabetes}

SIR,-While the frequency of childhood diabetes in Glasgow may indeed be on the increase, this cannot possibly be concluded from the data presented by $\mathrm{Dr} \mathrm{J} O \mathrm{O}$ Craig and his colleagues ( 5 March, p 639). Although their figures do, as they state, represent incidence (new cases per unit time) at the Royal Hospital for Sick Children, it is, of course, changes in incidence per unit population which are required if a change in frequency is to be demonstrated.

If the (rather shaky) assumptions are made that all new cases of childhood diabetes present at hospital and that the RHSC has a catchment population which has been consistent over time both in its size and in the comparability of its age structure to that of the City of Glasgow, then estimates of the child population of Glasgow may be applied to the data in order to show changes in frequency. If the Registrar General's decennial census figures for the 0-14-year age group in the City of Glasgow are employed as mid-decade estimates (interpolating for 1941) the numbers of cases to be expected relative to the 1933-6 incidence and population figures and the trend in the frequency of cases are as follows:

\begin{tabular}{|c|c|c|c|}
\hline \multirow{2}{*}{ Period } & \multicolumn{2}{|c|}{ No of cases } & \multirow{2}{*}{$\mathrm{O}: \mathrm{E}$} \\
\hline & $\begin{array}{c}\text { Observed } \\
(\mathrm{O})\end{array}$ & $\begin{array}{l}\text { Expected } \\
\text { (E) }\end{array}$ & \\
\hline $\begin{array}{l}1933-6 \\
1937-40 \\
1941-4 \\
1945-8 \\
1949-52 \\
1953-6 \\
1957-60 \\
1961-4 \\
1965-8 \\
1969-72 \\
1973-6\end{array}$ & $\begin{array}{r}27 \\
41 \\
17 \\
25 \\
19 \\
25 \\
39 \\
62 \\
48 \\
66 \\
113\end{array}$ & $\begin{array}{l}27 \\
25 \cdot 8 \\
25 \cdot 8 \\
24 \cdot 5 \\
24 \cdot 5 \\
24 \cdot 5 \\
25 \cdot 1 \\
25 \cdot 1 \\
21 \cdot 2 \\
21 \cdot 2 \\
21 \cdot 2\end{array}$ & $\begin{array}{l}1 \\
1 \cdot 6 \\
0 \cdot 7 \\
1 \cdot 0 \\
0 \cdot 8 \\
1 \cdot 0 \\
1 \cdot 6 \\
2 \cdot 5 \\
2 \cdot 3 \\
3 \cdot 1 \\
5 \cdot 3\end{array}$ \\
\hline
\end{tabular}

That these figures do in general reflect the trends described by Dr Craig and his colleagues in no way justifies their description of their raw data as demonstrating a "true increase of morbidity" and it is similarly to be hoped that others will consider sceptically their suggestion that "conversations with colleagues" provide an adequate substitute for hard data in relation to this question at national level.

A ScotT-SAMUel

Mersey Regional Health Authority,

Liverpool

\section{Fatal oxprenolol poisoning}

SIR,-We were interested in the account by Drs A Khan and J M Muscat-Baron of the death of a 57-year-old woman following an overdose of oxprenolol (26 February, p 552). It is somewhat surprising that loss of consciousness was one of the earliest manifestations of overdose with this drug. We wonder whether the salt emetic administered by the patient's husband could have contributed to her death. It is now well accepted that saline emetics can be dangerous ${ }^{1}$ and that their administration may lead to the rapid development of coma.: 3 Hypernatraemia, cerebral oedema, and congestion of the gastrointestinal mucosa are characteristic of salt poisoning. It is important to establish that these features were absent in the case described before accepting that the neurological findings were entirely due to oxprenolol.

Clive Roberts H MCNULTY

Bristol Royal Infirmary,

1 Lawson, A A H, British fournal of Hospital Medicine, 1976, 16, 333

Roberts, C J C, and Noakes, M J, Postgraduate Goodbody, $\mathrm{R}$ A et al, Medicine,

1975, 15, 261. et al, Medicine, Science, and the Law,

\section{Wound sepsis in colonic surgery}

SIR,-Dr A $\mathrm{T}$ Willis and his colleagues (5 March, p 607) are to be congratulated on the elimination of bacteroides sepsis with prophylactic metronidazole in 27 patients undergoing elective colonic surgery in whom no oral antibiotic bowel preparation was used.

Using Leigh's ${ }^{1}$ techniques of transport and culture, we have examined swabs or fragments of the incised colon and subcutaneous tissues as well as pus from any subsequent wound sepsis in 103 consecutive patients undergoing emergency or elective ileocolorectal surgery studied prospectively in two trials of antibiotic prophylaxis of wound sepsis. Sixty-one of these patients received oral antibacterial (as well as mechanical) bowel preparation, usually with a combination of phthalylsulphathiazole, neomycin, and tetracycline.

The wound sepsis rate when the bowel was prepared and the patient also protected by a single dose of $1 \mathrm{~g}$ of cephaloridine intraincisionally before skin closure was 3 out of $31(9.7 \%)$. When the bowel was prepared but ampicillin, saline irrigation, or povidoneiodine was used in the incision 10 patients out of $30(33.3 \%)$ suffered wound sepsis. These figures are comparable with the 4 (all aerobic) septic wounds out of $27(14.8 \%)$ in patients prepared with metronidazole in the series reported by Dr Willis and his colleagues. When no antibiotic preparation was used the corresponding rates with and without cephaloridine were 6 out of $15(40 \%)$ and 18 out of $27(66.7 \%)$ compared with 12 out of 19 $(63.2 \%)$ in Dr Willis's unprepared patients.

Bacteroides spp were isolated from only one patient (in organ, subcutaneous tissue, and pus) out of 61 who had had routine preparation compared with 9 out of $42(21.4 \%)$ from bowel specimens, 4 out of $42(9.5 \%)$ from subcutaneous tissue, and 12 out of 24 $(50 \%)$ from pus in patients who had had no antibacterial bowel preparation.

It would appear that long-established methods of bowel preparation are not inferior to metronidazole in the prevention of sepsis after colonic surgery. The rationale for a sevenday course of metronidazole after operation, when it is established that the main cause of wound sepsis is bacterial contamination of the abdominal wall during surgery, eludes us.

A V Pollock MARY Evans

Scarborough Hospital

' Leigh, D A, British Medical fournal, 1974, 3, 225. 